$\xi=-1$

\title{
Mutual fund investors perception in india-a study
}

\author{
R. Udhayasankar' ${ }^{*}$, K. Maran ${ }^{2}$ \\ ${ }^{1}$ Assistant Professor, Sri Sairam Institute of Technology, Chennai \\ ${ }^{2}$ Professor, Sri Sairam Institute of Management Studies, Chennai \\ *Corresponding author E-mail: udhayasankarr12@outlook.com
}

\begin{abstract}
Mutual fund is four decades old in India. It was started by UTI during the year 1964 with few schemes for small investors. During this short span of time it has made tremendous growth in Indian small investors. But now a day's its volume of investors and sources of investment also growing tremendous level. Moreover mutual fund scheme have added new dimension to overcome financial risk of small investors and also in fund raising capacity of corporate sectors. Mutual fund investors can diversify even more by purchasing different kind of stocks which will helps to spreading out investors' money across different types of derivative instruments and hence it reduces the risk tremendously up to certain extent and it is automatically diversify in a predetermined category of investments. This serves bridge work between small investors and corporate sectors likewise considering those points in this paper is an attempt to know the investors' perceptions towards selected mutual funds. This paper makes an attempt to identify various factors affecting perception of investors regarding investment in mutual funds. The findings will helpful to identify the investors' interest base and factors clearly and it reveals that the investors consider mutual funds as flexible investment option and it creates interest of investment among small investors.
\end{abstract}

Keywords: Mutual Fund, Investors Perception, Rate Of Return, Investment.

\section{Introduction}

A mutual fund is a financial intermediary that allows a group of investors to pool their money together with a predetermined investment objective. The mutual fund will have a fund manager who is responsible for investing the gathered money into specific securities (stocks or bonds). When investors invest in a mutual fund, they are buying units or portions of the mutual fund and thus on investing becomes a unit holder of the fund. Mutual funds are considered as one of the best available investments as compare to others they are very cost efficient and also easy to invest in, thus by pooling money together in a mutual fund, investors can purchase stocks or bonds with much lower trading costs than if they tried to do it on their own. But the biggest advantage to mutual funds is diversification, by minimizing risk \& maximizing returns. Mutual funds are set up to buy many stocks. Beyond that, investors can diversify even more by purchasing different kinds of stocks which helps to spreading out investors' money across different types of investments and hence, reduces risk tremendously up to certain extent. It could take you weeks to buy all these investments, but if you purchased a few mutual funds you could be done in a few hours because mutual funds automatically diversify in a predetermined category of investments.

\section{Mutual fund industry in india}

In the past decade, Indian mutual fund industry had seen a dramatic improvement, both qualities wise as well as quantity wise. Before, the monopoly of the market had seen an ending phase: the Assent under Management (AUM) was Rs.67bn. The private sector entry to the fund family raised the AUM to Rs.470bn in March 1993 and till April 2004; it reached the height of $1,540 \mathrm{bn}$. The main reason of its poor growth is that the mutual fund industry in India is new in the country. Large sections of Indian investors are yet to be intellect with the concept.
Hence, it is the prime responsibility of all mutual fund companies, to market the product correctly abreast of selling. The mutual fund industry can be broadly put into four phases according to the development of the sector, each phase is briefly described as under.

- The main purpose of doing this project was to know about mutual fund and its functioning. This helps to know in details about mutual fund industry right from its inception stage, growth and future prospects.

- It also helps in understanding different schemes of mutual funds. Because my study depends upon recent trends of mutual funds investment in India.

- The project study was done to ascertain the asset allocation, entry load, exit load, associated with the mutual funds. Ultimately this would help in understanding the benefits of mutual funds to investors.

\section{Objectives of study}

- To study on recent trends of mutual fund investments in India.

- To identify the investors basic perception against the mutual fund investment.

- To Identify and evaluate the recent trends of mutual fund investments in India.

\section{Review of literature}

Dietze, Oliver and Macro (2009) conducted a research Diet to evaluate the risk adjusted performance of European investment grade corporate bond mutual funds. Sample of 19 investment grade corporate bond funds was used for the period of 5 years (July 2000-June 2005). Funds were evaluated on the basis of single index model and several multi index and asset class factor 
models. Both maturity based indices and rating based indices were used to account for the risk and return characteristics of investment grade corporate bond funds. The results indicated that the corporate bond funds, on average, underperformed the benchmark portfolios and there was not a single fund exhibiting a significant positive performance. Results also indicated that the risk adjusted performance of larger and older funds, and funds charging lower fees were higher.

Sanjay Kumar Mishra and Manoj Kumar (2012) "How mutual fund investors objective and subjective knowledge impacts their information search and processing behaviour" in the article attempted to prove how Contrary to the popular belief that objective knowledge (OK) (that is, what is actually stored in the memory) and subjective knowledge (SK) (that is, what individuals perceive they know) differently impact information search and information-processing behavior, with an empirical study conducted on 268 mutual funds (MF). Investors suggest no significant difference in the impact of OK and SK on the width and depth of information search and information processing. The study suggested that OK and SK significantly positively impact the width and depth of information search and informationprocessing behaviour, however, no significant difference exists in the way they impact. The possible explanation put forward is that even though MF investors may suffer from self-deception (that is pseudo expertise) and report high knowledge (that is, high SK), the impact of SK on actual investment behaviour is not significantly different from that of OK

Lakshmi N (2015) in the research paper entitled "performance of the Indian MF industry a study with special reference to growth schemes" found out that MF serve those individuals including to invest but lack the newline technical investment expertise. Funds mobilized by the industry had grown new here by 57 percent and AUM by 14 percent during 1997-2006. Analysis of performance of newline seven schemes should that, all the sample schemes outperformed the newline market in terms of absolute returns without adequate returns to over total newline risk. All the three risk adjective performance measures showed newline underperformance of sample schemes.

Investors and fund Managers agreed newline that investing in MF were less risky. Goodwill was the main newline criterion of choosing MF organizations. Investors were moderately newline satisfied with the performance \& services offered by the industry. The study discussed in this project how the investor can be encouraged to maximize the return on their capital. To help the investor to guide about mutual funds to invest in Bonds, preference shares, equity shares for different age groups.

\section{Research design}

A Research design is the arrangement of conditions for collection and analysis of data in a manner that aims to combine relevance to the research purpose with economy in procedure. Research means acquiring new knowledge from events. Validity and reliability are closely related. So reliability is a precondition of validity. Research Design adopted in this study is Descriptive Research.

\section{Descriptive research}

There is general feeling that descriptive studies are factual and are very simple. This is not necessarily true. Descriptive studies can be complex demanding a high degree of scientific skill on the part of the researcher.

Descriptive studies are well structured. As was mentioned earlier an exploratory study needs a to be flexible in its approach that a descriptive study in contrast tends to be rigid and its approach cannot be changed every how and them. It is therefore necessary that the researcher gives sufficient thought to framing research questions and deciding the types of data to be collected and the procedure to be used for this purpose.

\section{Target respondents}

Survey method was adopted among the various categories of customers of Integrated Enterprises Ltd. 150 respondents were selected under convenient sampling techniques.

\section{Sampling technique and research design}

As the population is defined earlier the convenient sampling method is followed to draw the sample. In a convenient sample each member of the population has unknown and there is no equal chance of being selected. Convenient sampling technique is used in this study. The period of survey for collecting 150 questionnaires was 40 days.

\section{Data processing}

The collected data where analyzed and coded as per the objectives and the details of that were presented under the chapter on analysis and interpretation of data.

\section{Data sources}

Primary Data were collected through questionnaire and secondary data were collected from text books, references books, Annual reports and periodicals.

\section{Questionnaire}

The questionnaire is the method asking person to fill up the questionnaire. This method is primary data source of collecting of data.

\section{Statistical tools used for analysis}

Different statistical Tools can be used for analyzing and interpreting the data.

The various tools used in this study are;

- Weighted Mean

- Chi-Square Test

- Pearson Correlation Coefficient

\section{Hypothesis}

1. Products and services offered by Integrated Enterprises are sufficient

2. Occupation wise satisfaction towards motivation factors is independent.

3. Age wise satisfaction towards benefits derived is independent.

4. Education wise satisfaction towards pricing of Integrated Enterprises Products/Services is Independent.

\section{Analysis and interpretation}

Consumer's perception that were sought to be analyzed through this study is as follows:

- Product and services provided by Integrated Enterprises.

- Motivating factors.

- Benefits.

- Suggestions and recommendation by customer.

The data required was collected by means of a questionnaire survey. The data thus collected was classified according to the above factors were analyzed and inferences have been drawn with respect to the satisfaction levels of the worker have been classified as follows:

- Rate of return

- Low risk

- Brokerage

Each of the factors has been analyzed in detail below with representative sample respondents to the questionnaire. 
For calculating mean scores (X) Weighted rate method adopted. A sample of calculation of mean score by using weighted rate was given below.

The customers preference of investment in various schemes comparing Using Chi-square test

The given data can be tabulated as follows

Null hypothesis (Ho): There is a significant difference between customers of investment Schemes.

\begin{tabular}{|l|l|l|l|l|l|}
\hline Schemes & $\begin{array}{l}\text { Less } \\
\text { Than } \\
50000\end{array}$ & $\begin{array}{l}50001 \\
\text { To } \\
100000\end{array}$ & $\begin{array}{l}100001 \\
\text { To } \\
500000\end{array}$ & $\begin{array}{l}500001 \\
\text { To } \\
1000000\end{array}$ & Total \\
\hline Equity Schemes & 10 & 30 & 15 & 5 & 60 \\
\hline Debt Schemes & 6 & 21 & 10 & 2 & 39 \\
\hline Balanced Schemes & 3 & 18 & 6 & 2 & 29 \\
\hline Growth Schemes & 3 & 14 & 4 & 10 & 22 \\
\hline Total & 22 & 83 & 35 & 10 & 150 \\
\hline
\end{tabular}

Alternative hypothesis (H1): There is no significant difference between customer of Investment Schemes.

The table Expected Frequencies shall be follows:

$$
\begin{aligned}
& E_{11}=\frac{(A) \times(B)}{N}=\frac{60 \times 22}{150}=8.8 \\
& E_{21}=\frac{(A) \times(B)}{N}=\frac{39 \times 83}{150}=21.58
\end{aligned}
$$

\section{Applying chi-square test}

\begin{tabular}{|l|l|l|l|l|}
\hline $\mathrm{O}$ & $\mathrm{E}$ & $(\mathrm{O}-\mathrm{E})^{2}$ & $(\mathrm{O}-\mathrm{E})^{2}$ & $(\mathrm{O}-\mathrm{E})^{2} / \mathrm{E}$ \\
\hline 10 & 9 & 1 & 1 & 0.1111 \\
\hline 6 & 6 & 0 & 0 & 0.0000 \\
\hline 3 & 5 & -2 & 4 & 0.8 \\
\hline 3 & 4 & -1 & 1 & 0.25 \\
\hline 30 & 33 & -3 & 9 & 0.2727 \\
\hline 21 & 22 & -1 & 1 & 0.0454 \\
\hline 18 & 16 & 2 & 4 & 0.25 \\
\hline 14 & 12 & 2 & 4 & 0.3333 \\
\hline 15 & 14 & 1 & 1 & 0.0714 \\
\hline 10 & 9 & 1 & 1 & 0.1111 \\
\hline 6 & 7 & -1 & 1 & 0.1428 \\
\hline 4 & 5 & -1 & 1 & 0.2 \\
\hline 5 & 4 & 1 & 1 & 0.25 \\
\hline 2 & 3 & -1 & 1 & 0.333 \\
\hline 2 & 2 & 0 & 0 & 0.0000 \\
\hline 10 & 2 & 8 & 64 & 32 \\
\hline
\end{tabular}

Calculated value $=35.1708$

Total 35.1708

\section{To find tabular value}

Degree of freedom

$$
=(\mathrm{r}-1) *(\mathrm{c}-1)
$$$$
=(4-1) *(4-1)=9
$$

The tabular value at 9 Degree of freedom

$$
\text { At } 5 \% \text { level if significant }=16.919
$$

\section{Decision}

The calculated value is greater than the Tabular value $H_{1}$ is accepted.

There is no significant difference between customers Preference of investment schemes of Integrated Enterprises.

Table shows the investing factors to invest in mutual fund schemes using weighted average method

\begin{tabular}{|l|l|l|l|l|l|l|}
\hline Particular & $\begin{array}{l}\text { Rank } \\
\text { I }\end{array}$ & $\begin{array}{l}\text { Percentage } \\
(\%)\end{array}$ & $\begin{array}{l}\text { Rank } \\
\text { II }\end{array}$ & $\begin{array}{l}\text { Percentage } \\
(\%)\end{array}$ & $\begin{array}{l}\text { Rank } \\
\text { III }\end{array}$ & $\begin{array}{l}\text { Percentage } \\
(\%)\end{array}$ \\
\hline $\begin{array}{l}\text { Rate of } \\
\text { Return }\end{array}$ & 47 & 31.33 & 38 & 25.33 & 65 & 44.33 \\
\hline Low Risk & 32 & 21.33 & 46 & 30.67 & 72 & 48 \\
\hline Brokerage & 44 & 29.34 & 38 & 25.33 & 68 & 45.33 \\
\hline
\end{tabular}

\begin{tabular}{|l|l|l|l|l|l|l|}
\hline Total & 282 & 100 & 260 & 100 & 276 & 100 \\
\hline
\end{tabular}

(1) Rate of Retumn

\begin{tabular}{|c|c|c|c|}
\hline $\mathrm{Wi}$ & 47 & 38 & 65 \\
\hline $\mathrm{Xi}$ & 3 & 2 & 1 \\
\hline $\mathrm{Wi} \mathrm{Xi}$ & 141 & 76 & 65 \\
\hline
\end{tabular}

$$
\Sigma=\frac{\mathrm{WiXi}}{\mathrm{N}}=\frac{282}{150}
$$$$
=1.88
$$

(2) Low Risk

\begin{tabular}{|c|c|c|c|}
\hline $\mathrm{Wi}$ & 32 & 46 & 72 \\
\hline $\mathrm{Xi}$ & 3 & 2 & 1 \\
\hline $\mathrm{Wi} \mathrm{Xi}$ & 96 & 92 & 72 \\
\hline
\end{tabular}

$$
\Sigma=\frac{\mathrm{WiXi}}{\mathrm{N}}=\frac{260}{150}
$$$$
=1.73
$$

(3) Brokerage

\begin{tabular}{|l|c|c|c|}
\hline $\mathrm{Wi}$ & 44 & 38 & 68 \\
\hline $\mathrm{Xi}$ & 3 & 2 & 1 \\
\hline $\mathrm{Wi} \mathrm{Xi}$ & 132 & 76 & 68 \\
\hline
\end{tabular}

$$
\begin{aligned}
\Sigma=\frac{\mathrm{WiXi}_{\mathrm{Xi}}}{\mathrm{N}} & =\frac{276}{150} \\
& =1.84
\end{aligned}
$$

\section{Results}

\begin{tabular}{|l|l|l|}
\hline Ranking & Weighted Average & Attribute \\
\hline 1 & 1.88 & Rate of Return \\
\hline 2 & 1.84 & Brokerage \\
\hline 3 & 1.73 & Low risk \\
\hline
\end{tabular}

\section{Inference}

From the above table Majority of the respondent ranked that Rate of Return are the first important factor followed by Brokerage \&Low risk of the Influence to invest in Mutual fund schemes.

Table showing the level of satisfaction preference in mutual fund investment using pearson's correlation test

Calculation of Correlation Coefficient

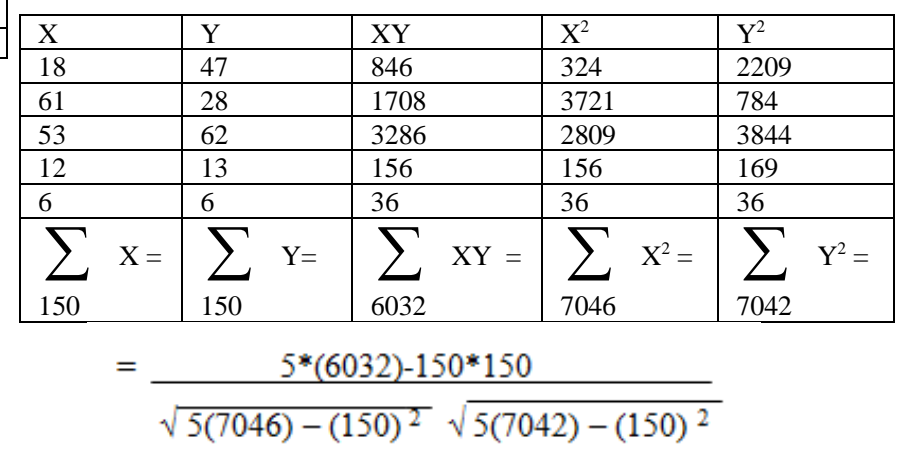

$r=0.60$

$\mathrm{r}$ value is positive and nearer to 1

\section{Inference}

There exists high degree of relationship between of level of customer's satisfaction on the mutual fund investment (X) \& reasons for preferring open ended \& closed ended schemes by customers( $\mathrm{Y}$ ) 


\section{Conclusion}

This study reveals that the investors feel that, the company should analysis perfectly before going to invest the specific fund schemes. The organization tries its level best to satisfy their customers by providing prompt services. The investors today are more sophisticated more selective and more demanding than ever before. Hence understanding the customer requirements can help the organization to survive and sustains and through in the long run.

\section{References}

[1] Arugaslan O, Edwards E \& Samant A, "Evaluating large US-based equity mutual funds using risk-adjusted performance measures", International Journal of Commerce and Management, Vol.17, No.1/2, pp.6-24, (2008).

[2] Rao SU, Ward D \& Ward S, "Empirical analysis of international mutual fund performance", International Business \& Economics Research Journal, Vol.6, No.5, (2007).

[3] Dietze LH, Entrop O \& Wilkens M, "The performance of investment grade corporate bond funds:evidence from the European market", The European Journal of Finance, Vol.15, No.2, pp.191209, (2009).

[4] Leite PA \& Cortez MC, "Conditional performance evaluation Evidence for the Portuguese mutual fund market", Portuguese Finance Network, (2006).

[5] Lakshmi, K., Surendar, A. "Verification of axiprotocol using system Verilog", (2017), International Journal of Mechanical Engineering and Technology, 8 (5), pp. 588-595.

[6] Surendar, A., Kavitha, M. "Secure patient data transmission in sensor networks", (2017), Journal of Pharmaceutical Sciences and Research, 9 (2), pp. 230-232.

[7] Surendar, A.'FPGA based parallel computation techniques for bioinformatics applications",(2017) International Journal of Research in Pharmaceutical Sciences, 8 (2), pp. 124-128.

[8] Surendar, A.'Evolution of gait biometric system and algorithms- A review" (2017) Biomedical and Pharmacology Journal, 10 (1), pp. 467-472.

[9] Panchumarthi, G.P., Surendar,A."A review article on Fin-FET based self-checking full adders",(2017) Journal of Advanced Research in Dynamical and Control Systems, 9 (4), 8 p.

[10] Priyanka Reddy, G.S., Surendar, A."A review article on performance comparison of CNTFET based full adders",(2017) Journal of Advanced Research in Dynamical and Control Systems, 9 (4), pp. 9-20.

[11] Selvi, N., Surendar, A. "Efficient power reduction and glitch free mux based digitally controlled delay line",(2015), International Journal of Applied Engineering Research, 10 (10), pp. 9655-9659. 